\title{
Discovery of novel TRPM8 blockers suitable for the treatment of somatic and ocular painful conditions: a journey through $\mathrm{p} K_{a}$ and $\operatorname{LogD}$ modulation
}

Gianluca Bianchini ${ }^{\mathrm{a}}$, Mara Tomassetti ${ }^{\mathrm{b}}$, Samuele Lillini ${ }^{\mathrm{b}}$, Anna Sirico ${ }^{\mathrm{b}}$, Silvia Bovolenta ${ }^{\mathrm{c}}$, Lorena $\mathrm{Za}^{\mathrm{c}}$, Chiara Liberati ${ }^{\mathrm{c}}$, Rubina Novelli ${ }^{\mathrm{d}}$ and Andrea Aramini ${ }^{\mathrm{a}^{*}}$

${ }^{a}$ Research and Early Development, Dompé Farmaceutici S.p.A., Via Campo di Pile, 67100, L’Aquila, Italy ${ }^{b}$ Research and Early Development, Dompé Farmaceutici S.p.A., Via De Amicis 95, 80131, Napoli, Italy ${ }^{\mathrm{c}}$ Axxam S.p.A, Via Meucci 3, 20091, Bresso, Italy

${ }^{\mathrm{d}}$ Research and Early Development, Dompé Farmaceutici S.p.A., Via Santa Lucia 6, 20122, Milano, Italy

${ }^{*}$ Corresponding Author

andrea.aramini@dompe.com

Table of contents:

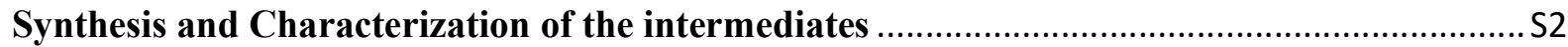

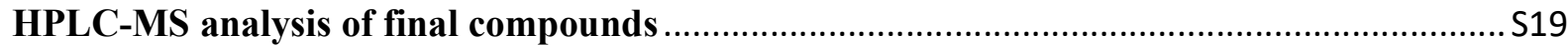

Table S1 with agonist and antagonist concentrations for calcium mobilization assay ............S24 


\section{Synthesis of ethyl 2-phenyl-1,3-thiazole-5-carboxylate (9)}

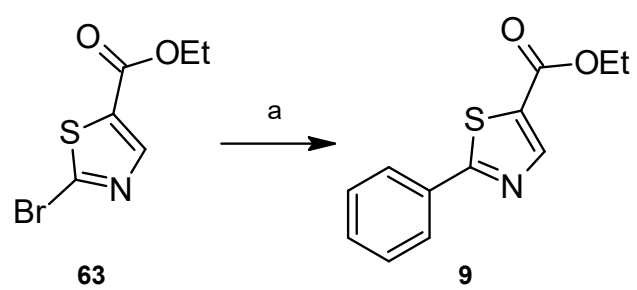

Reagents and conditions: a) Toluene (solvent), $\mathrm{Pd}\left(\mathrm{PPh}_{3}\right)_{4}(0.025 \mathrm{eq}), \mathrm{K}_{2} \mathrm{CO}_{3}(1 \mathrm{eq}), 80^{\circ} \mathrm{C}, 30 \mathrm{~min}$.

An oven-dried Schlenk tube equipped with a magnetic stir bar was charged with a $2 \mathrm{M}$ aqueous solution of potassium carbonate $(0.5 \mathrm{~mL}, 1 \mathrm{mmol})$, tetrakis(triphenylphosphine)palladium(0) (29 mg, $0.025 \mathrm{mmol}$ ) and $1.5 \mathrm{~mL}$ of toluene. The tube was capped with a rubber septum and immersed in an oil bath at $80{ }^{\circ} \mathrm{C}$ for $30 \mathrm{~min}$. To the reaction mixture were then added $\mathbf{6 3}(120 \mathrm{mg}, 0.5 \mathrm{mmol})$ and phenylboronic acid $(102 \mathrm{mg}, 0.75 \mathrm{mmol})$, and the reaction mixture was stirred at $80^{\circ} \mathrm{C}$ for $12 \mathrm{~h}$. The crude was filtered on celite pad, diluted with EtOAc and the extracted with water. The organic phase was washed with water and dried with sodium sulfate. The solvent was removed under reduced pressure and the crude was purified bysilica gel chromatography (Hexane/EtOAc 9:1) to obtain the title compound 9 as a white solid (122 mg, $0.483 \mathrm{mmol}, 95 \%$, purity 98\%). ${ }^{1} \mathrm{H}$ NMR (400 MHz, $\left.\mathrm{CDCl}_{3}\right) \delta 8.14(\mathrm{~s}, 1 \mathrm{H}), 8.00-7.94(\mathrm{~m}, 2 \mathrm{H}), 7.50-7.44(\mathrm{~m}, 3 \mathrm{H}), 4.39(\mathrm{q}, J=7.0 \mathrm{~Hz}, 2 \mathrm{H}), 1.40(\mathrm{t}, J=$ $7.0 \mathrm{~Hz}, 3 \mathrm{H})$. LC-MS (ESI positive ion) $\mathrm{m} / \mathrm{z}: 234.67(\mathrm{M}+1)$.

\section{Ethyl 4-hydroxy-2-(2-methoxyphenyl)-1,3-thiazole-5-carboxylate (86a)}

Following the general procedure A, using the 2-methoxybenzene-1-carbothioamide 61g, the title compound 86a was obtained as a yellow solid (70\%). ${ }^{1} \mathrm{H}$ NMR $\left(400 \mathrm{MHz}\right.$, acetone- $\left.d_{6}\right) \delta 8.83$ (br s, 1H), 7.49 (ddd, 2H, J = 2.6, 2.0, $1.2 \mathrm{~Hz}), 7.36(\mathrm{t}, 1 \mathrm{H}, \mathrm{J}=8.2 \mathrm{~Hz}), 7.05(\mathrm{ddd}, 1 \mathrm{H}, \mathrm{J}=8.1,2.3,1.1 \mathrm{~Hz})$, $2.89(\mathrm{q}, J=7.3 \mathrm{~Hz}, 2 \mathrm{H}), 2.09$ (s, 3H), 1.19 (t, $J=7.3 \mathrm{~Hz}, 3 \mathrm{H})$. LC-MS (ESI positive ion) $\mathrm{m} / \mathrm{z}: 280.06$ $(\mathrm{M}+1)$. 


\section{Ethyl 2-phenyl-4-[(trifluoromethanesulfonyl)oxy]-1,3-thiazole-5-carboxylate (62)}

To a solution of 5 (300 mg, $1.20 \mathrm{mmol})$ in dry DCM $(6 \mathrm{~mL})$, was added $\mathrm{Et}_{3} \mathrm{~N}(0.18 \mathrm{~mL}, 1.32 \mathrm{mmol})$ and the mixture was stirred for $40 \mathrm{~min}$ at room temperature. The reaction mixture was then cooled to $-10^{\circ} \mathrm{C}$ and trifluomethanesulfonic anhydride $(0.22 \mathrm{~mL}, 1.32 \mathrm{mmol})$ was added dropwise, keeping the temperature under $-5^{\circ} \mathrm{C}$. The reaction mixture was stirred for $12 \mathrm{~h}$ at room temperature. The reaction was quenched with saturated solution of $\mathrm{NH}_{4} \mathrm{Cl}(40 \mathrm{~mL})$. The aqueous layer was then extracted with EtOAc. The organic layers were further washed with brine and dried over sodium sulfate. The product was purified by silica gel chromatography (Hexane/EtOAc 8:2) to obtain the title compound $\mathbf{6 2}$ as a pale yellow solid. (228.3 mg, $0.59 \mathrm{mmol}, 50 \%) .{ }^{1} \mathrm{H}$ NMR (400 MHz, DMSO- $\left.d_{6}\right) \delta$ 7.67-7.63 (m, $\left.1 \mathrm{H}\right)$, 7.49-7.43 (m, 2H), 7.41-7.36 (m, 2H), $4.32(\mathrm{~d}, J=6.0 \mathrm{~Hz}, 2 \mathrm{H}), 1.36$ (t, $J=6.0 \mathrm{~Hz}, 3 \mathrm{H})$. LC-MS (ESI positive ion) $\mathrm{m} / \mathrm{z}: 382.00(\mathrm{M}+1)$.

\section{Ethyl 4-amino-2-phenyl-1,3-thiazole-5-carboxylate (11)}

$\mathrm{Pd}_{2}(\mathrm{dba})_{3}(7.11 \mathrm{mg}, 0.0078 \mathrm{mmol})$ and xantphos $(15.04 \mathrm{mg}, 0.026 \mathrm{mmol})$ were dissolved in dry THF (4 mL) under $\mathrm{N}_{2}$ atmosphere. The mixture was stirred at room temperature for $20 \mathrm{~min} .62$ (100 mg, $0.26 \mathrm{mmol})$ was then added, followed by tert-butyl carbamate $(0.035 \mathrm{~mL}, 0.28 \mathrm{mmol})$ after $5 \mathrm{~min}$. The mixture was irradiated by microwave at $135^{\circ} \mathrm{C}$ for $1 \mathrm{~h}$. The solvent was removed under reduced pressure and the crude was purified bysilica gel chromatography to obtain ethyl 4-[(tertbutoxycarbonyl)amino]-2-phenyl-1,3-thiazole-5-carboxylate (67.03 mg, $0.19 \mathrm{mmol}, 74 \%$ ). The resulting carbamate was dissolved in $1.25 \mathrm{M} \mathrm{HCl}$ in $\mathrm{CH}_{3} \mathrm{OH}$, the solution was stirred for $1 \mathrm{~h}$ at room temperature. The solvent was removed under reduced pressure to obtain the title compound $\mathbf{1 1}$ as bright yellow solid (45.28 mg, $0.182 \mathrm{mmol}, 95 \%$, purity 98.4\%). ${ }^{1} \mathrm{H}$ NMR (400 MHz, DMSO- $\left.d_{6}\right) \delta$ $7.67(\mathrm{dd}, J=7.5,1.2 \mathrm{~Hz}, 1 \mathrm{H}), 7.48-7.43(\mathrm{~m}, 2 \mathrm{H}), 7.40-7.35(\mathrm{~m}, 2 \mathrm{H}), 5.38$ (br s, 2H), 4.31 (d, $J=6.0$ $\mathrm{Hz}, 2 \mathrm{H}), 1.37$ (t, $J=6.0 \mathrm{~Hz}, 3 \mathrm{H})$. LC-MS (ESI positive ion) m/z: $249.06(\mathrm{M}+1)$. 


\section{Ethyl 2-(4-chlorophenyl)-4-hydroxy-1,3-oxazole-5-carboxylate (21)}

Following the general procedure $\mathbf{A}$ and using 4-chlorobenzamide, the title compound 21 was obtained as off white solid (83\%, purity $98.5 \%) .{ }^{1} \mathrm{H}$ NMR (400 MHz, DMSO- $\left.d_{6}\right) \delta 12.2$ (br s, $\left.1 \mathrm{H}\right)$, $7.89(\mathrm{~d}, J=8.6 \mathrm{~Hz}, 2 \mathrm{H}), 7.56(\mathrm{~d}, J=8.7 \mathrm{~Hz}, 2 \mathrm{H}), 4.13(\mathrm{q}, J=7.1 \mathrm{~Hz}, 2 \mathrm{H}), 1.24(\mathrm{t}, J=6.9 \mathrm{~Hz}, 3 \mathrm{H})$. LC-MS (ESI positive ion) m/z: $268.03(\mathrm{M}+1)$.

\section{Synthesis of ethyl 3'-fluoro-3-hydroxy[1,1'-biphenyl]-4-carboxylate (22)}<smiles>CCOC(=O)c1ccc(-c2cccc(F)c2)cc1O</smiles>

Reagents and conditions: a) EtOH (solvent), $0^{\circ} \mathrm{C}, \mathrm{SOCl}_{2}$ (3 eq); overnight, reflux. b) $\mathrm{H}_{2} \mathrm{O}$ (solvent), Boronic Acid (1.1 eq), $\mathrm{Na}_{2} \mathrm{CO}_{3}$ (3 eq), $\mathrm{Pd}(\mathrm{OAc})_{2}$ (0.01 eq); rt, overnight.

\section{Synthesis of ethyl 3'-fluoro-3-hydroxy[1,1'-biphenyl]-4-carboxylate (22)}

4-bromo-2-hydroxybenzoic acid $71(217 \mathrm{mg}, 1 \mathrm{mmol})$ was dissolved in ethanol and cooled at $0^{\circ} \mathrm{C}$. Then thionyl chloride $(0.218 \mathrm{~mL}, 3 \mathrm{mmol})$ was added and the resulting solution was heated at reflux overnight. After cooling at room temperature, the mixture was evaporated under reduced pressure and used without further purification.

Ethyl 4-bromo-2-hydroxybenzoate 72 (245 mg, $1 \mathrm{mmol}), \mathrm{Na}_{2} \mathrm{CO}_{3}(318 \mathrm{mg}, 3 \mathrm{mmol}), \mathrm{PhB}(\mathrm{OH})_{2}$, (134 mg, $1.1 \mathrm{mmol}$ ) were dissolved in $\mathrm{H}_{2} \mathrm{O}(4 \mathrm{~mL})$ under argon. Then $\mathrm{Pd}(\mathrm{OAc})_{2}(2.2 \mathrm{mg}, 0.01 \mathrm{mmol})$ was added. The reaction mixture was stirred at room temperature overnight. Then Pd-black was filtered off. The filtrate was diluted with water $(150 \mathrm{~mL})$ and treated with $1 \mathrm{M} \mathrm{HCI}$ until $\mathrm{pH} 1$. The precipitate was filtered off, washed with water and dried over $\mathrm{P}_{2} \mathrm{O}_{5}$ under reduced pressure to give $164 \mathrm{mg}\left(63 \%\right.$, purity $98.3 \%$ ) of compound $22 .{ }^{1} \mathrm{H}$ NMR (400 MHz, $\left.\mathrm{CDCl}_{3}\right): \delta 11.01$ (br s, $\left.1 \mathrm{H}\right), 7.90$ $(\mathrm{d}, J=8.3 \mathrm{~Hz}, 1 \mathrm{H}), 7.42-6.90(\mathrm{~m}, 6 \mathrm{H}), 4.39(\mathrm{q}, J=7.0,2 \mathrm{H}), 1.40(\mathrm{t}, J=7.0,3 \mathrm{H})$. LC-MS (ESI positive ion) $\mathrm{m} / \mathrm{z}$ : $261.17(\mathrm{M}+1)$. 


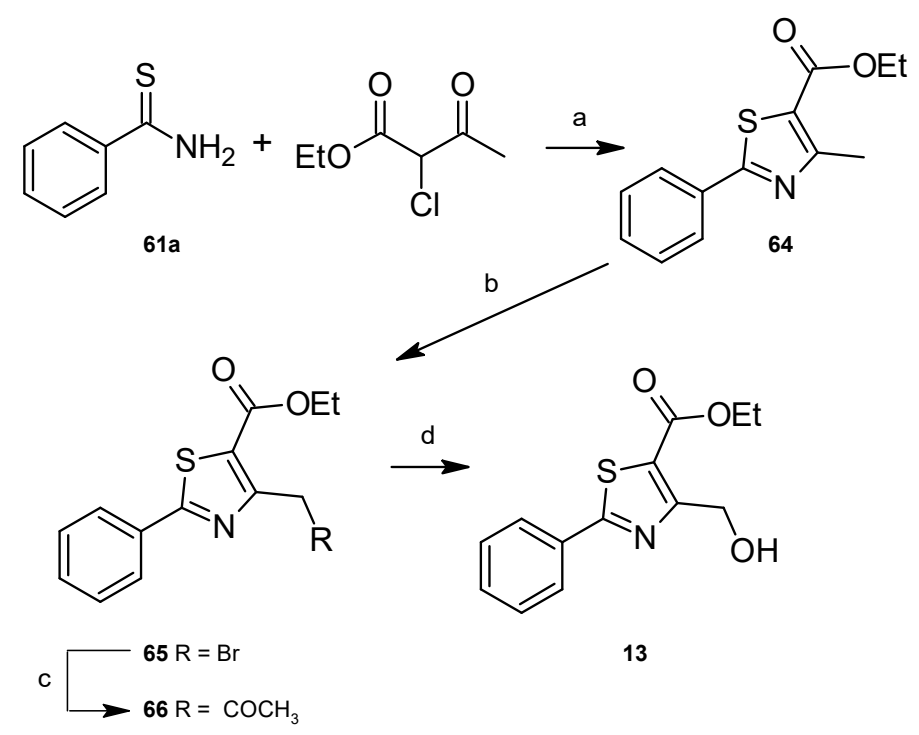

Reagents and conditions: a) General procedure $\mathbf{A}$ (b) $\mathrm{CCl}_{4}$ (solvent), NBS (1.05 eq), benzoylperoxide $(0.1 \mathrm{eq}), 80^{\circ} \mathrm{C}, 3 \mathrm{~h}, 80 \%$ (c) $\mathrm{AcOH}, \mathrm{AcONa}, 120^{\circ} \mathrm{C}, 47 \%$; (d) $\mathrm{THF}$ (solvent), $3 \mathrm{~N}$ aq $\mathrm{HCl}, \mathrm{rt}, 98 \%$;

\section{Synthesis of ethyl 4-methyl-2-phenyl-1,3-thiazole-5-carboxylate (64)}

Following the general procedure A, using benzenecarbothioamide 61a and ethyl 2-chloro-3oxobutanoate, the title compound $\mathbf{6 4}$ was obtained as a white solid (68\%). LC-MS (ESI positive ion) $\mathrm{m} / \mathrm{z}: 248.07(\mathrm{M}+1)$.

\section{Synthesis of ethyl 4-(bromomethyl)-2-phenyl-1,3-thiazole-5-carboxylate (65)}

To a solution of $64(400 \mathrm{mg}, 1.22 \mathrm{mmol})$ in $\mathrm{CCl}_{4}(12 \mathrm{~mL})$ was added $\mathrm{N}$-Br-succinimide (206 mg, $1.16 \mathrm{mmol}$ ) followed by the addition of benzoyl peroxide (37 $\mathrm{mg}, 0.15 \mathrm{mmol}$ ) and the reaction was heated at $80^{\circ} \mathrm{C}$ for $3 \mathrm{~h}$. The reaction was diluted with DCM and the organic phase was washed with water. The organic phase was dried with sodium sulfate and the solvent was removed under reduced pressure to obtain the title compound $\mathbf{6 5}$ as a white solid (318 $\mathrm{mg}, 0.974 \mathrm{mmol}, 80 \%)$ that was used without further purification. LC-MS (ESI positive ion) m/z: $326.20(\mathrm{M}+1)$. 


\section{Synthesis of ethyl 4-[(acetyloxy)methyl]-2-phenyl-1,3-thiazole-5-carboxylate (66)}

To a stirred solution of $\mathbf{6 5}(300 \mathrm{mg}, 0,97 \mathrm{mmol})$ in acetic acid $(2 \mathrm{~mL})$ was added sodium acetate $(1.59$ g, $19.4 \mathrm{mmol}$ ) and the reaction was warmed at $120^{\circ} \mathrm{C}$ and stir for $1 \mathrm{~h}$. The crude was diluted with a saturated solution of sodium bicarbonate and the aqueous phase was extracted with DCM. The organic phase was washed with water and dried with sodium sulfate. The solvent was removed under reduced pressure and the crude was purified bysilica gel chromatography (Hexane/EtOAc 9:1) to obtain the title compound $\mathbf{6 6}$ as a white solid (140 mg, $0.46 \mathrm{mmol}, 47 \%)$. LC-MS (ESI positive ion) $\mathrm{m} / \mathrm{z}: 306.47(\mathrm{M}+1)$.

\section{Synthesis of ethyl 4-(hydroxymethyl)-2-phenyl-1,3-thiazole-5-carboxylate (13)}

To a stirred solution of $\mathbf{6 6}(70 \mathrm{mg}, 0,23 \mathrm{mmol})$ in THF $(2 \mathrm{~mL})$ was added a $3 \mathrm{~N}$ aqueous solution of $\mathrm{HCl}(2 \mathrm{~mL})$ and the reaction was left to stir at room temperature for $6 \mathrm{~h}$. The crude was diluted with water and the aqueous phase was extracted with EtOAc. The organic phase was washed with brine and dried with sodium sulfate. The solvent was removed under reduced pressure to obtain the title compound 13 as a white powder (59 mg, $0.22 \mathrm{mmol}, 98 \%$, purity 98.4\%). ${ }^{1} \mathrm{H}$ NMR (400 MHz, $\left.\mathrm{CDCl}_{3}\right): \delta 7.78-7.72(\mathrm{~m}, 2 \mathrm{H}), 7.48-7.43(\mathrm{~m}, 2 \mathrm{H}), 7.25-7.13(\mathrm{~m}, 1 \mathrm{H}), 5.01(\mathrm{~s}, 2 \mathrm{H}), 4.43(\mathrm{q}, J=7.05$ $\mathrm{Hz}, 2 \mathrm{H}), 1.48$ (t, $J=7.03 \mathrm{~Hz}, 3 \mathrm{H})$. LC-MS (ESI positive ion) m/z: $264.21(\mathrm{M}+1)$.

\section{Synthesis of ethyl (4-hydroxy-2-phenyl-1,3-thiazol-5-yl)acetate (14)}

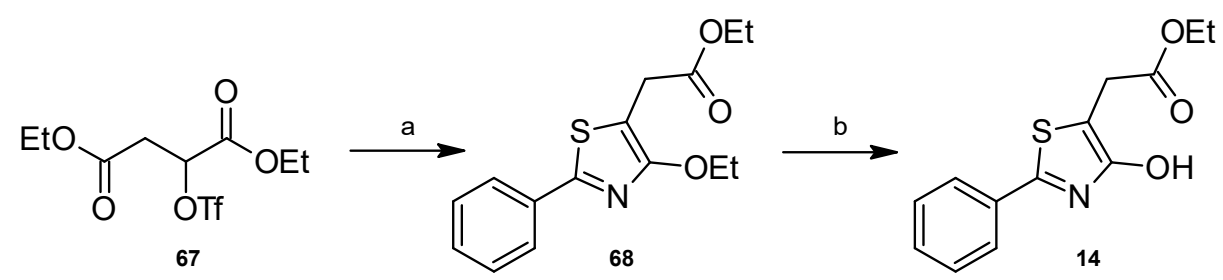

Reagents and conditions: a) General procedure A (b) General procedure F

\section{Synthesis of diethyl 2-[(trifluoromethanesulfonyl)oxy]butanedioate (67)}


To a solution of the commercially available diethyl 2-hydroxybutanedioate $(1.54 \mathrm{~mL}, 10.1 \mathrm{mmol})$ in dry DCM $(50 \mathrm{~mL})$ was added $\mathrm{Et}_{3} \mathrm{~N}(1.4 \mathrm{~mL}, 10.1 \mathrm{mmol})$ and the mixture was stirred for $40 \mathrm{~min}$ at room temperature. The reaction mixture was then cooled to $-10^{\circ} \mathrm{C}$ and trifluomethanesulfonic anhydride $(1.7 \mathrm{~mL}, 10.1 \mathrm{mmol})$ was added dropwise, keeping the temperature under $-5^{\circ} \mathrm{C}$. The reaction mixture was stirred for $12 \mathrm{~h}$ at room temperature. The mixture was washed with a saturated solution of $\mathrm{NH}_{4} \mathrm{Cl}$. The aqueous layer was extracted with EtOAc. The organic phase was washed with brine and dried with sodium sulfate. The solvent was removed under reduced pressure to obtain the title compound $\mathbf{6 7}$ that was used without further purification. LC-MS (ESI positive ion) m/z: 323.25 $(\mathrm{M}+1)$.

\section{Synthesis of ethyl (4-ethoxy-2-phenyl-1,3-thiazol-5-yl)acetate (68)}

Following the general procedure A, using 67 and benzenecarbothioamide 61a, the title compound 68 was obtained as a white solid (75\%). LC-MS (ESI positive ion) m/z: $292.26(\mathrm{M}+1)$.

\section{Synthesis of ethyl (4-hydroxy-2-phenyl-1,3-thiazol-5-yl)acetate (14)}

Following the general procedure $\mathbf{F}$, using 68, the title compound $\mathbf{1 4}$ was obtained as a white solid (75\%, purity 98.3\%). ${ }^{1} \mathrm{H}$ NMR (400 MHz, $\left.\mathrm{CDCl}_{3}\right): \delta 8.20(\mathrm{~d}, J=8.3 \mathrm{~Hz}, 1 \mathrm{H}), 7.80-7.26(\mathrm{~m}, 4 \mathrm{H})$, $4.54(\mathrm{~s}, 2 \mathrm{H}), 4.12(\mathrm{q}, J=8.1 \mathrm{~Hz}, 2 \mathrm{H}), 1.34(\mathrm{t}, J=8.1 \mathrm{~Hz}, 3 \mathrm{H})$. LC-MS (ESI positive ion) m/z: 264.06 $(\mathrm{M}+1)$.

Synthesis of methyl 5-hydroxy-2-phenyl-1,3-thiazole-4-carboxylate (15)<smiles>COC(=O)C(NC(=O)c1ccccc1)C(=O)OC</smiles> 
Reagents and conditions: (a)THF (solvent), Lawesson's reagent (0.6 eq), rt, overnight, (b) dioxane (solvent) $\mathrm{POCl}_{3}(0.6 \mathrm{eq}), 100^{\circ} \mathrm{C}, \mathrm{MW}$.

\section{Synthesis of dimethyl benzamidopropanedioate (69)}

To a stirred solution of the commercially available dimethyl aminomalonate hydrochloride $(2.0 \mathrm{~g}$, $10.8 \mathrm{mmol})$ in DCM $(40 \mathrm{~mL})$ was added $\mathrm{Et}_{3} \mathrm{~N}(3.4 \mathrm{~mL}, 24 \mathrm{mmol})$ followed by the addition of benzoyl chloride $(1.39 \mathrm{~mL}, 11.88 \mathrm{mmol})$ and the reaction was left to stir at room temperature overnight. The mixture was washed with a saturated solution of sodium bicarbonate, $1 \mathrm{M} \mathrm{HCl}$ and water. The organic phase was dried with sodium sulfate and the solvent was removed under reduced pressure to obtain the title compound 69 as a white solid (2.6 g, $10.35 \mathrm{mmol}, 96 \%$ ). LC-MS (ESI positive ion) m/z: $251.23(\mathrm{M}+1)$.

\section{Synthesis of dimethyl [(benzenecarbothioyl)amino]propanedioate (70)}

To a stirred solution of $\mathbf{6 9}(2.50 \mathrm{~g}, 9.95 \mathrm{mmol})$ in THF $(50 \mathrm{~mL})$ was added Lawesson reagent $(2.4 \mathrm{~g}$, $5.97 \mathrm{mmol}$ ) and the reaction was left to stir overnight at room temperature. The solvent was removed under reduced pressure and the crude was purified by silica gel chromatography (Hexane/EtOAc 8:2) to obtain the title compound 70 as a bright yellow solid (2.2 g, $8.45 \mathrm{mmol}, 85 \%)$. LC-MS (ESI positive ion) $\mathrm{m} / \mathrm{z}: 268.06(\mathrm{M}+1)$.

\section{Synthesis of methyl 5-hydroxy-2-phenyl-1,3-thiazole-4-carboxylate (15)}

Compound 70 (2.0 g, $7.48 \mathrm{mmol})$ was dissolved in dioxane $(35 \mathrm{~mL})$ and phosphoryl chloride $(0.42$ $\mathrm{mL}, 4.48 \mathrm{mmol}$ ) was added. The mixture was irradiated by microwave at $100^{\circ} \mathrm{C}$ for $15 \mathrm{~min}$, and the solvent was removed under reduced pressure. The title compound $\mathbf{1 5}$ was obtained by trituration with acetonitrile as a yellow solid (1.47 g, $6.28 \mathrm{mmol}, 84 \%$, purity 98.8\%). LC-MS (ESI positive ion) m/z: $236.03(\mathrm{M}+1)$.

\section{Rac-ethyl (3E)-3-amino-3-(hydroxyimino)propanoate (74)}


To a solution of ethyl cyanoacetate $(10 \mathrm{~g}, 88 \mathrm{mmol})$ in EtOH $(100 \mathrm{~mL})$ was added sodium carbonate ( $7 \mathrm{~g}, 66 \mathrm{mmol}$ ) followed by hydroxylamine hydrochloride $(9.2 \mathrm{~g}, 69.5 \mathrm{mmol})$, then $50 \mathrm{~mL}$ of water was added dropwise. The reaction was left to run at room temperature overnight and then stir at $50^{\circ} \mathrm{C}$ for $1 \mathrm{~h}$. The residual precipitate was filtrate and the organic phase was evaporated under reduced pressure. The aqueous phase was extracted with DCM. The collected organic phase was washed with brine and dried with sodium sulfate. The solvent was removed under reduced pressure to obtain the title compound 74 as a brown oil $(5.14 \mathrm{~g}, 35.19 \mathrm{mmol}, 40 \%)$. The compound was used without further purification. GC-MS (EI positive ion) $\mathrm{m} / \mathrm{z}: 146.1(\mathrm{M})^{++}$.

\section{Ethyl (5-methyl-1,2,4-oxadiazol-3-yl)acetate (75)}

To a solution of $74(5.4 \mathrm{~g}, 36.6 \mathrm{mmol})$ in acetonitrile $(15 \mathrm{~mL})$ was added $p-\mathrm{TsOH} \cdot \mathrm{H}_{2} \mathrm{O}(2.1 \mathrm{~g}, 11$ $\mathrm{mmol})$ and $\mathrm{ZnCl}_{2}(1.5 \mathrm{~g}, 11 \mathrm{mmol})$ under $\mathrm{N}_{2}$. The reaction was left to stir at reflux for $48 \mathrm{~h}$. The crude was diluted with EtOAc and the organic phase was washed with saturated solution of sodium bicarbonate and water. The organic phase was washed with brine and dried with sodium sulfate. The crude was purified by silica gel chromatography (Hexane/EtOAc 6:4) to obtain the title compound 75 as a colorless oil (1.55 g, $9.11 \mathrm{mmol}, 25 \%)$. LC-MS (ESI positive ion) m/z: $171.07(\mathrm{M}+1)$.

\section{Ethyl bromo(5-methyl-1,2,4-oxadiazol-3-yl)acetate (76)}

To a cooled solution of $75(154 \mathrm{mg}, 0.91 \mathrm{mmol})$ in dry $\mathrm{THF}(5 \mathrm{~mL})$ at $0^{\circ} \mathrm{C}$, was added diazobicyclo[5.4.0] undec-7-ene $(0.165 \mathrm{~mL}, 1.1 \mathrm{mmol})$ and the reaction was left to stir for $1 \mathrm{~h}$. The solution was then cooled to $-78^{\circ} \mathrm{C}$ and was added a solution of $\mathrm{CBr}_{4}(223 \mathrm{mg}, 0.67 \mathrm{mmol})$ dissolved in THF (1 $\mathrm{mL}$ ) and the reaction was left to stir for $1 \mathrm{~h}$. The reaction was quenched with saturated solution of $\mathrm{NH}_{4} \mathrm{Cl}$ and the aqueous phase was extracted with EtOAc. The collected organic phase was dried with sodium sulfate. The crude was purified by silica gel chromatography (Hexane/EtOAc 7:3) to afford the title compound 76 as a brown oil (124 mg, $0.5 \mathrm{mmol}, 55 \%$ ). LC-MS (ESI positive ion) m/z: 248.98 $(\mathrm{M}+1)$. 


\section{2-(3-Fluorophenyl)-4-(methoxymethoxy)-1,3-thiazole-5-carboxylic acid (77)}

To a solution of $20(0.500 \mathrm{~g}, 1.87 \mathrm{mmol})$ in DMF $(20 \mathrm{~mL}), \mathrm{K}_{2} \mathrm{CO}_{3}(258.43 \mathrm{mg}, 3.74 \mathrm{mmol})$ was added and the mixture was heated at $60^{\circ} \mathrm{C}$ under stirring. After $15 \mathrm{~min}, \mathrm{MOMCl}(4.41 \mathrm{~mL}, 4.67$ mmol) was added and the mixture was stirred overnight at the same temperature. After cooling to room temperature, EtOAc was added and the mixture was washed with water. The organic phase was dried with sodium sulfate and the solvent was removed under reduced pressure. The crude product was purified by HPLC to obtain ethyl 2-(3-fluorophenyl)-4-(methoxymethoxy)-1,3-thiazole-5carboxylate intermediate (558 $\mathrm{mg}, 1.79 \mathrm{mmol}, 96 \%)$.

Ethyl 2-(3-fluorophenyl)-4-(methoxymethoxy)-1,3-thiazole-5-carboxylate was then dissolved in dioxane $(3 \mathrm{~mL})$ and $1 \mathrm{M}$ sodium hydroxide $(1.3 \mathrm{~mL}, 1.0 \mathrm{mmol})$ was added. The mixture was stirred at room temperature overnight and the reaction was quenched with $5 \mathrm{~mL}$ of water. After washing with DCM, the aqueous phase was acidified with $1 \mathrm{M} \mathrm{HCl}$ to $\mathrm{pH} 3-4$ and extracted with EtOAc. The organic layers were further washed with brine and dried with sodium sulfate. The solvent was removed under reduced pressure to obtain the title compound 77 as a white solid ( $466 \mathrm{mg}, 1.66 \mathrm{mmol}$, 92\%) as white solid. LC-MS (ESI positive ion) m/z: $284.03(\mathrm{M}+1)$.

\section{2-(3-Fluorophenyl)-4-(methoxymethoxy)-1,3-thiazole-5-carboxamide (78)}

To a solution of $77(100 \mathrm{mg}, 0.35 \mathrm{mmol})$ in dry DCM $(10 \mathrm{~mL})$ at $0^{\circ} \mathrm{C}$ under $\mathrm{N} 2$ atmosphere, $1,1^{\prime}-$ carbonyldiimidazole $(85.12 \mathrm{mg}, 0.52 \mathrm{mmol})$ was added at the same temperature. The mixture was warmed to room temperature and stirred for $40 \mathrm{~min} . \mathrm{NH}_{3}(\mathrm{~g})$ was bubbled in the mixture. The mixture was concentrated under reduced pressure and the crude was purified by silica gel chromatography (Hexane/EtOAc 8:2) to obtain the title compound 78 as a white solid (74.35 mg, $0.26 \mathrm{mmol}, 75 \%$ ). LC-MS (ESI positive ion) m/z: $283.15(\mathrm{M}+1)$. 


\section{2-(3-Fluorophenyl)-4-(methoxymethoxy)-1,3-thiazole-5-carbonitrile (79)}

A $250 \mathrm{~mL}$ three-necked round bottom flask was equipped with a thermometer under nitrogen and charged with a solution of $78(450 \mathrm{mg}, 1.5 \mathrm{mmol})$ in dry DCM $(8 \mathrm{~mL})$. To this solution was added DMSO $(0.33 \mathrm{~mL}, 4.2 \mathrm{mmol})$ and the resulting pale-yellow solution was cooled to $-78^{\circ} \mathrm{C}$. A solution of $(\mathrm{COCl})_{2}(0.286 \mathrm{~mL}, 3.34 \mathrm{mmol})$ in $2 \mathrm{~mL}$ of dry DCM was then added via cannula. After stirring for $15 \mathrm{~min}$ at $-78^{\circ} \mathrm{C}, \mathrm{Et} 3 \mathrm{~N}(0.912 \mathrm{~mL}, 6.55 \mathrm{mmol})$ was added dropwise to the mixture.

The reaction was quenched by addition of water. The reaction mixture was then warmed to room temperature, and aqueous layer was extracted with EtOAc. The combined organic phases were washed with brine and dried over sodium sulfate. The solvent was removed under reduced pressure and the crude was purified by silica gel chromatography (Hexane/EtOAc 9:1) to obtain the title compound 79 as a pale yellow solid (310.9 mg, $1.17 \mathrm{mmol}$, 74\%). LC-MS (ESI positive ion) $\mathrm{m} / \mathrm{z}$ : $265.09(\mathrm{M}+1)$.

\section{Ethyl (1-ethyl-1H-tetrazol-5-yl)acetate (81) and ethyl (2-ethyl-2H-tetrazol-5-yl)acetate (83)}

To a cooled solution of the commercially available ethyl (2H-tetrazol-5-yl)acetate 80 (10 g, 64.04 mmol) in acetonitrile $(40 \mathrm{~mL})$ at $0^{\circ} \mathrm{C}, \mathrm{Et}_{3} \mathrm{~N}(10.72 \mathrm{~mL}, 76.92 \mathrm{~mol})$ was added followed by the addition of iodoethane $(10.29 \mathrm{~mL}, 128.2 \mathrm{mmol})$ and the reaction was left to run at room temperature overnight. The solvent was removed under reduced pressure and the crude was dissolved in ethyl acetate and the organic phase was washed with water and sodium metabisulfite. The aqueous phase was extracted with EtOAc, and the collected organic phases were dried with sodium sulfate. The regio-isomers were separated by silica gel chromatography (Hexane/EtOAc 1:1) to afford compound $\mathbf{8 1}(\mathrm{Rf}=0.5)$ and compound $83(\mathrm{Rf}=0.9)$ as light oils.

Compound 81: GC-MS (EI positive ion) m/z: $184.42(\mathrm{M})^{+}$. Compound 83: GC-MS (EI positive ion) $\mathrm{m} / \mathrm{z}: 184.23(\mathrm{M})^{\cdot+}$.

\section{Ethyl chloro(1-ethyl-1H-tetrazol-5-yl)acetate (82)}


To a stirred solution of 81 (250 mg, $1.35 \mathrm{mmol})$ in dry DCM $(9 \mathrm{~mL})$ was added $N$-chloro-succinimide $(217 \mathrm{mg}, 1.62 \mathrm{mmol})$ followed by the addition of zirconium tetrachloride (16 $\mathrm{mg}, 0.067 \mathrm{mmol})$ and the reaction was left to stir at room temperature overnight. The crude was dried and was re-dissolved in $\mathrm{EtOH}(1.5 \mathrm{~mL})$. The solvent was removed under reduced pressure to afford $82(276 \mathrm{mg}, 1.18 \mathrm{mmol}$, 93\%) that was used without further purification. ${ }^{1} \mathrm{H} \mathrm{NMR}\left(400 \mathrm{MHz}, \mathrm{CDCl}_{3}\right) \delta 5.91(\mathrm{~s}, 1 \mathrm{H}), 4.52(\mathrm{q}$, $J=7.3 \mathrm{~Hz}, 2 \mathrm{H}), 4.31(\mathrm{q}, J=7.3 \mathrm{~Hz}, 2 \mathrm{H}), 1.57$ (t, $J=7.3 \mathrm{~Hz}, 3 \mathrm{H}), 1.27$ (t, $J=7.3 \mathrm{~Hz}, 3 \mathrm{H}) . \mathrm{GC}-\mathrm{MS}$ (EI positive ion) $\mathrm{m} / \mathrm{z}: 218.6(\mathrm{M})^{++}$.

\section{Ethyl (2-methyl-2H-tetrazol-5-yl)acetate (84)}

Following the same procedure used for the synthesis of compound $\mathbf{8 3}$, and using methyl iodide, the title compound $\mathbf{8 4}$ was obtained as a white solid (58\%). GC-MS (EI positive ion) m/z: 140.00 (M$\mathrm{Et})^{++}$.

\section{Ethyl bromo(2-ethyl-2H-tetrazol-5-yl)acetate (85a)}

To a stirred solution of $\mathbf{8 3}(5.53 \mathrm{~g}, 30.05 \mathrm{mmol})$ in dioxane/EtOH $(20 \mathrm{~mL})$ was added a $2 \mathrm{M}$ aqueous solution $\mathrm{NaOH}(30.03 \mathrm{~mL}, 30.05 \mathrm{mmol})$ and the reaction was left to stir overnight at room temperature. The solvent was removed under reduced pressure and the crude was dissolved in $\mathrm{HCl}$ $1 \mathrm{~N}$ and extracted with EtOAc. The organic phase was washed with brine and dried with sodium sulfate. The solvent was removed under reduced pressure and the crude was purified by silica gel chromatography (DCM/MeOH 8:2) to obtain (2-ethyl-2H-tetrazol-5-yl)acetic acid as white solid (2.95 g, $18.89 \mathrm{mmol}, 63 \%)$. GC-MS (EI positive ion) $\mathrm{m} / \mathrm{z}: 127.41(\mathrm{M})^{-+}$. To a cooled solution at $0^{\circ} \mathrm{C}$,

(2-ethyl-2H-tetrazol-5-yl)acetic acid (3.17 g, $20.30 \mathrm{mmol})$ was dissolved in DCM $(75 \mathrm{~mL})$ and phosphorus trichloride was added $(0.90 \mathrm{~mL}, 10.15 \mathrm{mmol})$ followed by dropwise addition of bromine (1.03 mL, $20.31 \mathrm{mmol}$ ). The reaction was warmed to $45^{\circ} \mathrm{C}$ and was left to stir for $3 \mathrm{~h}$. The reaction was quenched with EtOH and diluted with DCM. The organic phase was washed with water and 
brine. The organic phase was dried with sodium sulfate and the crude was purified by silica gel chromatography (Hexane/EtOAc 8:2) to afford the title compound 85a as a white powder (3.29 $\mathrm{g}$, $12.55 \mathrm{mmol}, 62 \%) .{ }^{1} \mathrm{H}$ NMR (400 MHz, $\left.\mathrm{CDCl}_{3}\right) \delta 5.71(\mathrm{~s}, 1 \mathrm{H}), 4.72(\mathrm{q}, J=7.3 \mathrm{~Hz}, 2 \mathrm{H}), 4.32$ (q, $J=$ $7.3 \mathrm{~Hz}, 2 \mathrm{H}), 1.68$ (t, $J=7.3 \mathrm{~Hz}, 3 \mathrm{H}), 1.32$ (t, $J=7.3 \mathrm{~Hz}, 3 \mathrm{H})$. GC-MS (EI positive ion) m/z: 234.94, $232.84(\mathrm{M}-\mathrm{Et})^{++}$.

Ethyl bromo(2-methyl-2H-tetrazol-5-yl)acetate (85b)

Following the same procedure described for compound $\mathbf{8 5 a}$ and starting from $\mathbf{8 4}$, the title compound 85b was obtained as a yellow solid (68\%). GC-MS (EI positive ion) m/z: 234.94, $232.84(\mathrm{M}-\mathrm{Me})^{++}$.

\section{Ethyl 2-(3-fluorophenyl)-4-methoxy-1,3-thiazole-5-carboxylate (87a)}

Following the general procedure $\mathbf{B}$ and using 20, the title compound $\mathbf{8 7} \mathbf{a}$ was obtained as a pale yellow solid (75\%). LC-MS (ESI positive ion) m/z: $282.05(\mathrm{M}+1)$.

ethyl 4-methoxy-2-(2-methoxyphenyl)-1,3-thiazole-5-carboxylate (87b)

Following the general procedure $\mathbf{B}$ and starting from $\mathbf{8 6 a}$, the title compound $\mathbf{8 7} \mathbf{b}$ was obtained as a yellow solid (83\%). LC-MS (ESI positive ion) m/z: $294.07(\mathrm{M}+1)$.

\section{General procedure C: synthesis of 2-(3-fluorophenyl)-4-methoxy-1,3-thiazole-5-carboxylic acid} (88a)

To a stirred solution of $\mathbf{8 7 a}(97 \mathrm{mg}, 0.345 \mathrm{mmol})$ in ethanol/water $(3 \mathrm{~mL} / 0.020 \mathrm{~mL})$ was added $\mathrm{KOH}$ (193 mg, $3.44 \mathrm{mmol}$ ) and the reaction was left to stir overnight at room temperature. The mixture was diluted with water and acidified with $2 \mathrm{~N} \mathrm{HCl}$ to $\mathrm{pH} 2$ and extracted with EtOAc. The collected organic phase was washed with water and brine then dried with sodium sulfate. The solvent was removed under reduced pressure to obtain the title compound $\mathbf{8 8 a}(83 \mathrm{mg}, 0.326 \mathrm{mmol}, 95 \%)$ as a white solid. LC-MS (ESI positive ion) $\mathrm{m} / \mathrm{z}: 254.2(\mathrm{M}+1)$. 


\section{2-(2-hydroxyphenyl)-4-methoxy-1,3-thiazole-5-carboxylic acid (88b)}

Following the general procedure $\mathbf{C}$ and starting from $\mathbf{8 7 b}$, the title compound $\mathbf{8 8 b}$ was obtained as a yellow solid (96\%). LC-MS (ESI positive ion) m/z: $266.0(\mathrm{M}+1)$.

General procedure D: synthesis of 2-(3-fluorophenyl)-N,4-dimethoxy-N-methyl-1,3-thiazole-5carboxamide (89a)

To a stirred solution, equipped with a cooled condenser, of $\mathbf{8 8 a}(100 \mathrm{mg}, 0.592 \mathrm{mmol})$ in dry DCM $(10 \mathrm{~mL})$ was added thionyl chloride $(0.085 \mathrm{~mL}, 1.18 \mathrm{mmol})$ followed by the addition of catalytic amount of dry DMF $(0.004 \mathrm{~mL})$ and the reaction was refluxed for 2.5 hours. The solution was cooled, and the volatiles were removed under reduced pressure. The oily residue was stripped three times with toluene to afford 2-(3-fluorophenyl)-4-methoxy-1,3-thiazole-5-carbonyl chloride. The chloride was thus re-dissolved in dry DCM $(5 \mathrm{~mL})$, under $\mathrm{N}_{2}$, and the solution was cooled to $0^{\circ} \mathrm{C}$. To this solution was added $\mathrm{N}, \mathrm{O}$-dimethylhydroxylamine hydrochloride $(72.07 \mathrm{mg}, 1.18 \mathrm{mmol})$ followed by the addition of triethylamine $(0.206 \mathrm{~mL}, 1.48 \mathrm{mmol})$ and the reaction was left to stir until completion. The crude was diluted with DCM and the organic phase was washed with water and brine. The organic phase was dried with sodium sulfate and the solvent was removed under reduced pressure to obtain the title compound 89a that was used for the next step without further purification (166 mg, 0.562 mmol, 95\%). LC-MS (ESI positive ion) m/z: $297.07(\mathrm{M}+1)$.

General procedure E: synthesis of 1-[2-(3-fluorophenyl)-4-methoxy-1,3-thiazol-5-yl]ethan-1one (90a) 
A solution of $89 \mathrm{a}(66 \mathrm{mg}, 0.222 \mathrm{mmol})$ in dry THF $(2.5 \mathrm{~mL})$ was cooled to $-78^{\circ} \mathrm{C}$, then a solution of methyl magnesium chloride (3M in THF, $0.168 \mathrm{~mL}, 0.112 \mathrm{mmol})$ was added and the reaction was left to stir at $-60^{\circ} \mathrm{C}$ for 1.5 hours. The reaction was quenched, at room temperature, with saturated solution of $\mathrm{NH}_{4} \mathrm{Cl}$. The mixture was extracted with EtOAc and the organic phase was washed with water, brine and dried with sodium sulfate. The solvent was removed under reduced pressure and the crude was purified by silica gel chromatography (Hexane/EtOAc 9:1) to obtain the title compound 90a as a yellow solid (53 mg, $0.210 \mathrm{mmol}, 95 \%)$. LC-MS (ESI positive ion) m/z: $252.04(\mathrm{M}+1)$.

\section{1-[2-(3-Fluorophenyl)-4-methoxy-1,3-thiazol-5-yl]propan-1-one (90b)}

Following the general procedure $\mathbf{E}$ and using 89a and ethyl magnesium chloride, the title compound 90b was obtained as a pale yellow solid (94\%). LC-MS (ESI positive ion) m/z: $266.06(\mathrm{M}+1)$.

\section{1-[2-(3-Fluorophenyl)-4-methoxy-1,3-thiazol-5-yl]butan-1-one (90c)}

Following the general procedure $\mathbf{E}$ and using 89a and propyl magnesium chloride, the title compound 90c was obtained as a yellow solid (93\%). LC-MS (ESI positive ion) m/z: $280.08(\mathrm{M}+1)$.

\section{1-[2-(3-Fluorophenyl)-4-methoxy-1,3-thiazol-5-yl]-2-methylpropan-1-one (90d)}

Following the general procedure $\mathbf{E}$ and using 89a and iso-propyl magnesium chloride, the title compound 90d was obtained as a yellow solid (96\%). LC-MS (ESI positive ion) m/z: $280.08(\mathrm{M}+1)$.

\section{1-[2-(3-Fluorophenyl)-4-methoxy-1,3-thiazol-5-yl]-3-methylbutan-1-one (90e)}

Following the general procedure $\mathbf{E}$ and using 89a and iso-butyl magnesium chloride, the title compound 90e was obtained as a pale-yellow solid (96\%). LC-MS (ESI positive ion) m/z: 294.05 $(\mathrm{M}+1)$. 


\section{General procedure G: synthesis of N-ethoxy-2-(3-fluorophenyl)-5-methoxy-N-methyl-1,3- thiazole-4-carboxamide (91a)}

To a cooled solution of 88a $(1 \mathrm{~g}, 3.77 \mathrm{mmol})$ in dry DMF $(60 \mathrm{~mL})$ was added $\mathrm{Et}_{3} \mathrm{~N}(2.62 \mathrm{~mL}, 4.14$ $\mathrm{mmol})$ at $0^{\circ} \mathrm{C}$, followed by the addition of EDC (793 mg, $\left.4.14 \mathrm{mmol}\right)$. After 5 minutes, HOBt (559 $\mathrm{mg}, 4.14 \mathrm{mmol}$ ) was added and the reaction was left to stir for 30 minutes. Then, $N$ ethoxymethanamine hydrochloride $(436 \mathrm{mg}, 5.65 \mathrm{mmol}$ ) was added and the reaction was left to warm to room temperature and stir overnight. The reaction was quenched with water $(25 \mathrm{~mL})$ and stir for 10 minutes. The crude was diluted with EtOAc and the organic phase was washed with $1 \mathrm{~N} \mathrm{HCl}$ and sodium bicarbonate and dried with sodium sulfate. The solvent was evaporated under reduced pressure to obtain the title compound 91a (943 $\mathrm{mg}, 3.18 \mathrm{mmol}, 84 \%)$ as a pale yellow solid that was used for the next step without further purification. LC-MS (ESI positive ion) m/z: $311.08(\mathrm{M}+1)$.

\section{[2-(3-fluorophenyl)-5-methoxy-1,3-thiazol-4-yl](1,2-oxazolidin-2-yl)methanone (91b)}

Following the general procedure $\mathbf{G}$, using 88a and 1,2-oxazolidine hydrochloride, the title compound 91b was obtained as a pale yellow solid (78\%). LC-MS (ESI positive ion) m/z: $309.07(\mathrm{M}+1)$.

\section{[2-(3-fluorophenyl)-5-methoxy-1,3-thiazol-4-yl](1,2-oxazinan-2-yl)methanone (91c)}

Following the general procedure $\mathbf{G}$, using $\mathbf{8 8 a}$ and 1,2-oxazinane hydrochloride, the title compound 91c was obtained as a pale yellow solid (81\%). LC-MS (ESI positive ion) m/z: $323.08(\mathrm{M}+1)$.

\section{[2-(3-fluorophenyl)-5-methoxy-1,3-thiazol-4-yl](1,2-oxazepan-2-yl)methanone (91d)}

Following the general procedure G, using 89a and 1,2-oxazepane hydrochloride, the title compound 91d was obtained as a pale yellow solid (79\%). LC-MS (ESI positive ion) m/z: $337.10(\mathrm{M}+1)$. 


\section{[2-(3-fluorophenyl)-5-methoxy-1,3-thiazol-4-yl](1,3-oxazolidin-3-yl)methanone (91e)}

Following the general procedure G, using 89a and 1,3-oxazolidine hydrochloride, the title compound 91e was obtained as a pale yellow solid (80\%). LC-MS (ESI positive ion) m/z: $309.06(\mathrm{M}+1)$.

\section{[2-(3-fluorophenyl)-5-methoxy-1,3-thiazol-4-yl](1,3-oxazinan-3-yl)methanone (91f)}

Following the general procedure G, using 89a and 1,3-oxazinane hydrochloride, the title compound 91f was obtained as a pale yellow solid (78\%). LC-MS (ESI positive ion) m/z: $323.09(\mathrm{M}+1)$.

\section{[2-(3-fluorophenyl)-5-methoxy-1,3-thiazol-4-yl](morpholin-4-yl)methanone (91g)}

Following the general procedure $\mathbf{G}$, using $89 \mathbf{a}$ and morpholine, the title compound $91 \mathrm{~g}$ was obtained as a pale yellow solid (76\%). LC-MS (ESI positive ion) m/z: $323.04(\mathrm{M}+1)$.

\section{4-hydroxy-N-methoxy-2-(2-methoxyphenyl)-N-methyl-1,3-thiazole-5-carboxamide (92a)}

Following the general procedure $\mathbf{G}$, using $\mathbf{8 8 b}$ and $N, O$-dimethylhydroxylamine hydrochloride, the title compound 92a was obtained as a pale yellow solid (75\%). LC-MS (ESI positive ion) m/z: 308.04 $(\mathrm{M}+1)$.

\section{N-ethoxy-5-methoxy-2-(2-methoxyphenyl)-N-methyl-1,3-thiazole-4-carboxamide (92b)}

Following the general procedure $\mathbf{G}$, using $\mathbf{8 8 b}$ and N-ethoxymethanamine hydrochloride, the title compound 92b was obtained as a pale yellow solid (XX\%). LC-MS (ESI positive ion) m/z:

\section{[5-methoxy-2-(2-methoxyphenyl)-1,3-thiazol-4-yl](1,2-oxazolidin-2-yl)methanone (92c)}

Following the general procedure $\mathbf{G}$, using $\mathbf{8 8 b}$ and 1,2-oxazolidine hydrochloride, the title compound 92c was obtained as a pale yellow solid (75\%). LC-MS (ESI positive ion) $\mathrm{m} / \mathrm{z}$ : 323.15 $(\mathrm{M}+1)$. 
[5-methoxy-2-(2-methoxyphenyl)-1,3-thiazol-4-yl](1,2-oxazinan-2-yl)methanone (92d)

Following the general procedure $\mathbf{G}$, using $\mathbf{8 8 b}$ and 1,2-oxazinane hydrochloride, the title compound 92d was obtained as a pale yellow solid (79\%). LC-MS (ESI positive ion) m/z: $321.09(\mathrm{M}+1)$. 


\section{HPLC-MS analysis of final compounds}
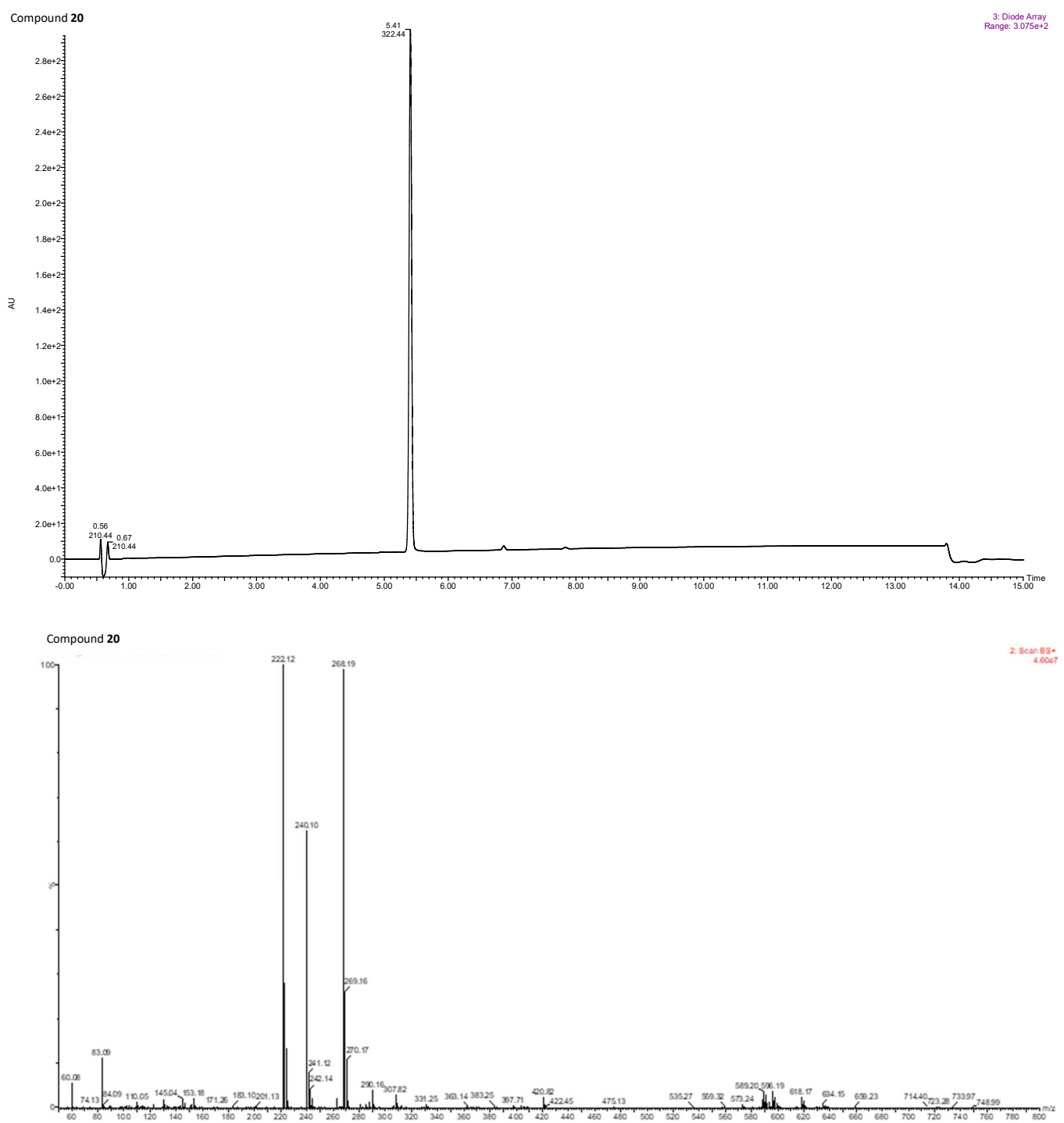

HPLC-MS of compound $\mathbf{2 0}$ 


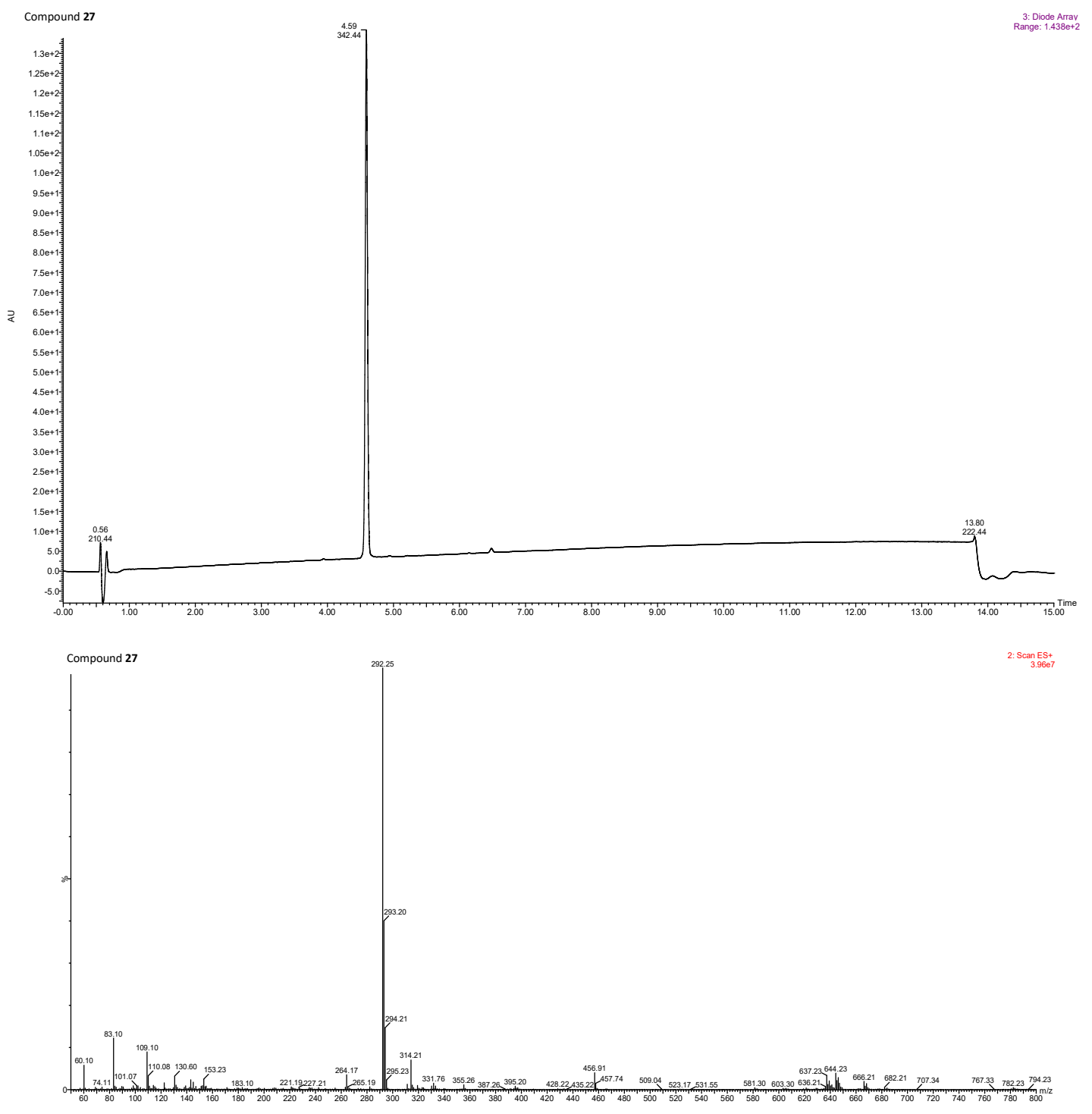

HPLC-MS of compound 27 


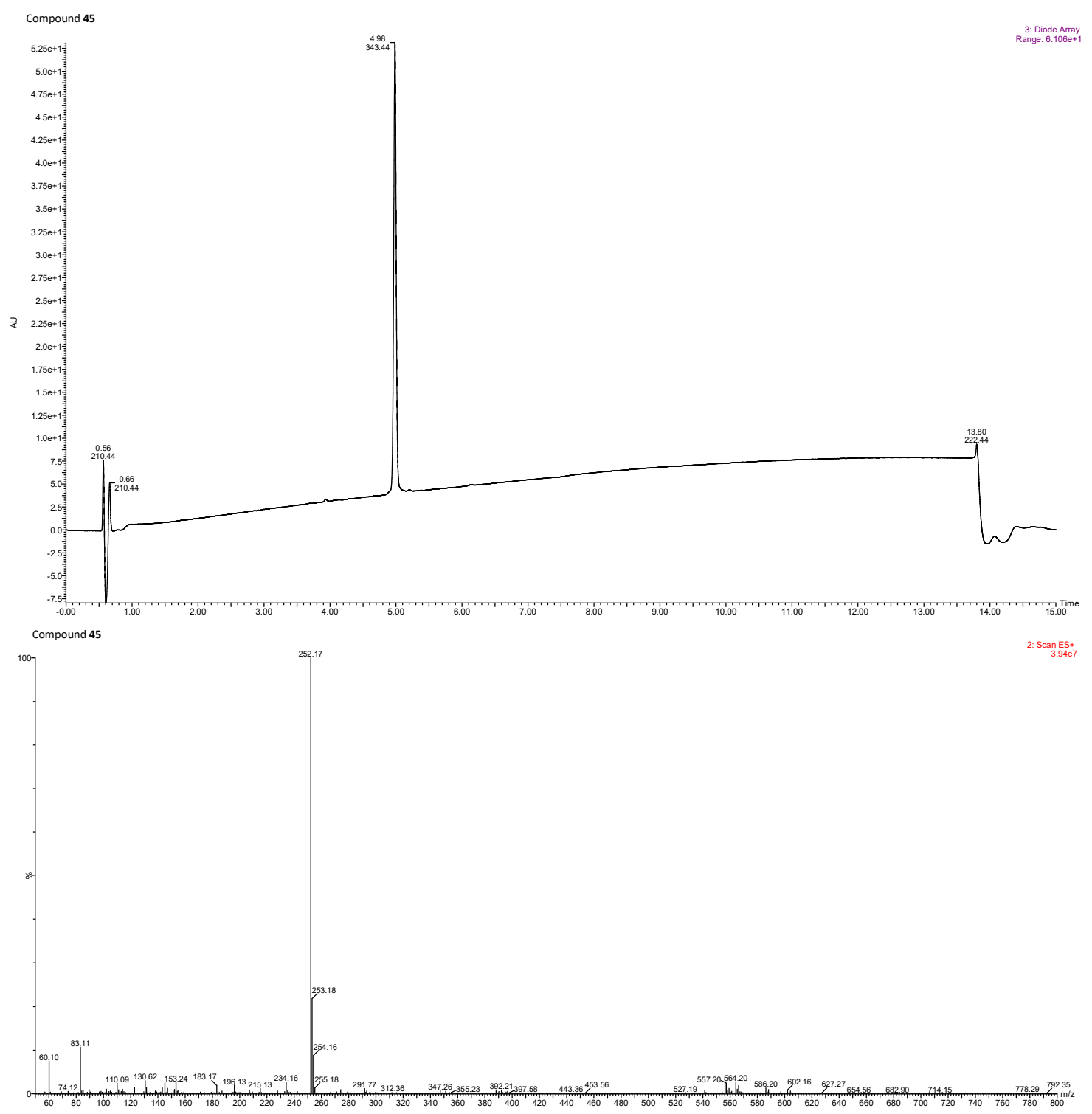

HPLC-MS of compound $\mathbf{4 5}$ 

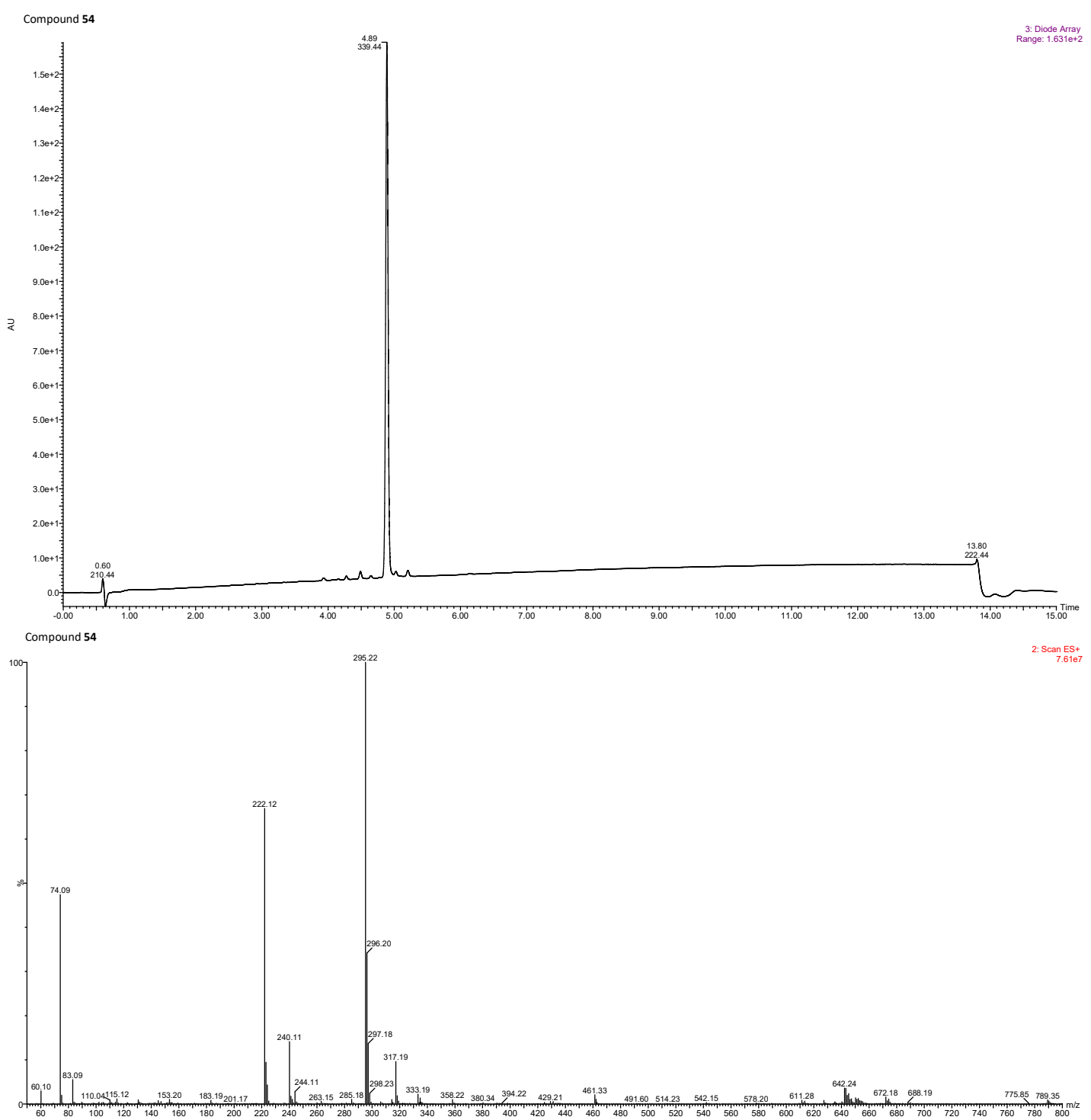

HPLC-MS of compound $\mathbf{5 1}$ 


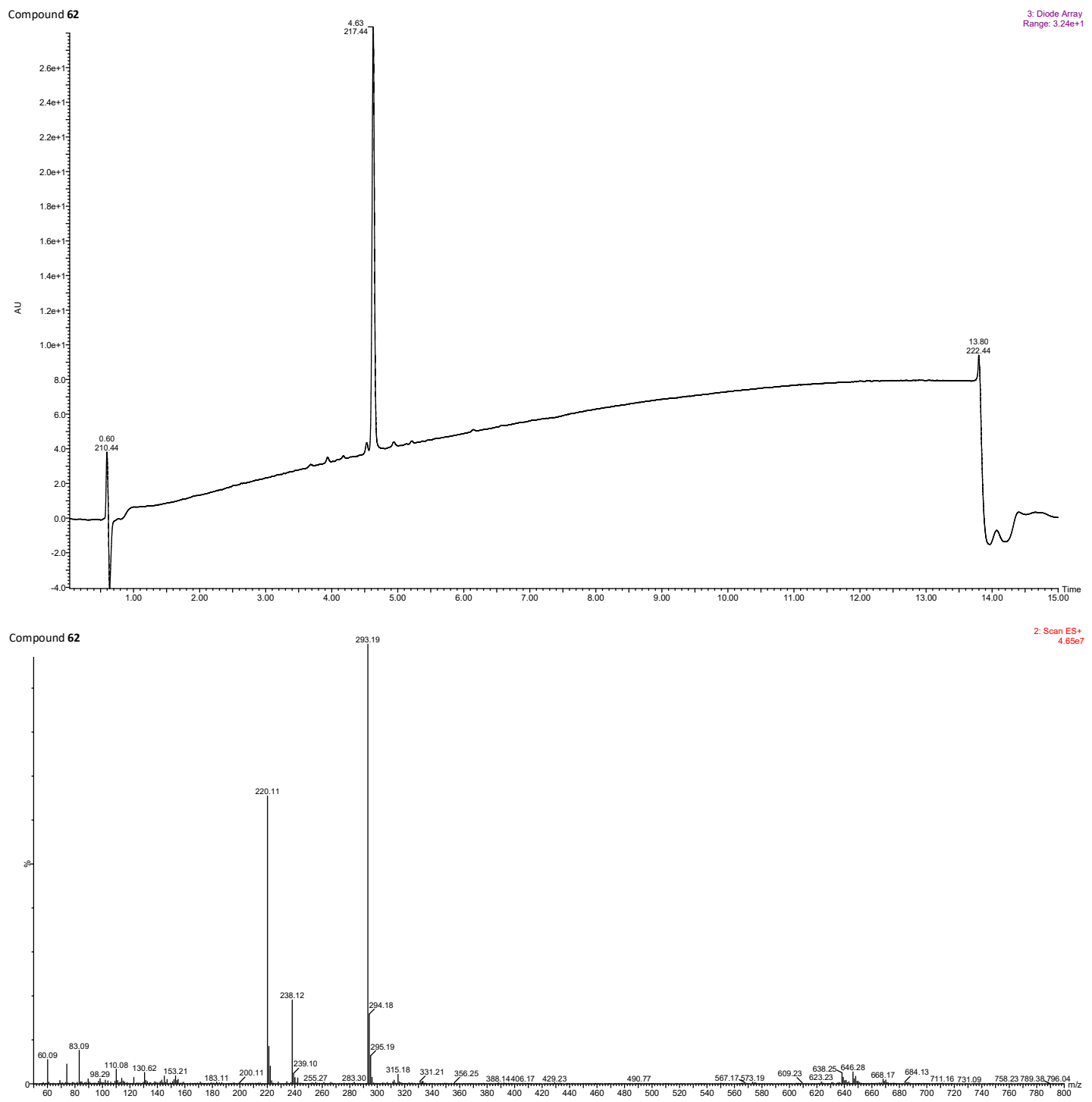

HPLC-MS of compound $\mathbf{5 9}$ 


\begin{tabular}{|c|c|c|}
\hline Experiment & Agonist $[\mathrm{C}]$ & Antagonist $[\mathrm{C}]$ \\
\hline $\mathrm{IC}_{50}$ determination Dose-response & $\begin{array}{l}\text { Cooling agent } 10: 30 \mu \mathrm{M} \\
\text { Icilin: } 650 \mathrm{nM}\end{array}$ & $\begin{array}{l}\text { Compound } 1 \text { Vs cooling agent } \\
10 \text { ( } 10 \text { concentrations half log } \\
\text { increment): From } 3.16 * 10-5 \mathrm{M} \\
\text { to } 1 * 10-9 \mathrm{M} \\
\text { Compound } 1 \text { Vs icilin }(10 \\
\text { concentrations half log } \\
\text { increment): From } 3.16 * 10-4 \mathrm{M} \\
\text { to } 10 * 10-8 \mathrm{M}\end{array}$ \\
\hline $\begin{array}{l}\text { Mutants activity } \\
\text { I746A, N799A, D802A, WT, MOCK }\end{array}$ & $\begin{array}{l}\text { Cooling agent } 10: 30, \\
30,480,120,30,30 \mu \mathrm{M} \\
\text { Icilin: } 350, \mathrm{na}, 650, \mathrm{na}, \\
650,650 \mathrm{nM}\end{array}$ & $\begin{array}{l}\text { (10 concentrations half log } \\
\text { increment): From } 3.16^{*} 10-5 \mathrm{M} \\
\text { to } 1 * 10-9 \mathrm{M}\end{array}$ \\
\hline
\end{tabular}

Table S1: Agonist and antagonist concentrations [C] for each calcium mobilization experiment 